\title{
IMPROVEMENT OF DESCRIPTION TEXT WRITING SKILLS THROUGH THE APPLICATION OF THE CLUSTERING METHOD FOR STUDENTS
}

\author{
Tin Hadriani ${ }^{1^{*}}$ \\ ${ }^{1}$ SMA Negeri 1 Tengaran, Semarang district, Central Java, Indonesia \\ tinhardiani10@gmail.com
}

DOI: https://doi.org/10.21107/Widyagogik/v8i1.8642

Received September 14, 2020; Revised September 23, 2020; Accepted October 2, 2020

\section{Abstract}

Writing skill is a competency that the student should accive in the end of teaching and learning process, in each genre they learned. Description text is a texs that, learned in grade ten $(x)$ in the first semester. Description text is text that decribe place, thing and people in detail. The structure text of description text are identification and description the language features of description text are. Use-present tense, noun phrase and passive sentence. In fact there are many student who cannot write the description text well. Their paragraph is bad, they use the wrong tense, diction and noun phrase. Their creativity is still low there is few students who answer and ask to the teacher, if they have problem and they are afraid to share their ideas so the researcher try to do the class action researh using clustering method to increase the students, skill in writing description text : This class action researh is carried out in class XIPS 4 SMAN 1 Tengaran 2014/2015 academic year in first semester. Based on this class action research, using clustering method can increase students' writing skill in writing description text

Keywords - writing skill,description text,clusstering method 
27 Improvement of Description Text Writing Skills Through The Application of The Clustering Method for Students

Tin Hadriani

\section{Introduction}

In learning English, students are required to have competency in reading, writing, speaking, and listening, based on the genre or type of text being studied. The value of writing descriptive text skills in class X IPS 4 SMA N 1 Tengaran odd semester $2014 / 2015$ academic year is still low. This is proven by the results of the test scores for writing skills are still far below the KKM determined by the school, namely 70 . The lowest score achieved by students is 56 , while the highest score is 85 with an average score of 60 . During the learning process, some students cannot complete their essays. Some students only write a few sentences. At the first meeting, when students were asked to make a layout/essay framework, some students could not complete the layout/outline. At the second meeting, some students could complete their assignments well, but there were still students who had not been able to complete their assignments. The sentences that were created were not well structured, many of the ideas written were ambiguous. The paragraphs they made still bring up a lot of ideas. The ideas they come up with are not detailed in each paragraph. The sentences they created are still not grammatically correct.

At the first and second meetings, the researchers had not used the clustering method. The learning at that time used the lecture method after which the researchers immediately gave writing assignments to students. Students are required to have the skills to write descriptive text well so that students can describe an object, place, or person well. The skills of writing the descriptive text for class X IPS 4 SMA N 1 Tengaran odd semester 2014/2015 academic year are low. This is evident from the results of the tests that are still under the KKM, therefore researchers need to apply a "clustering" method strategy in learning so that students' writing skills can improve. With the application of the clustering method strategy, the researcher hopes that the skills in writing descriptive texts of class X IPS 4 SMA N 1 Tengaran in the odd semester of the 2014/2015 academic year will increase. The expected improvement starts with increasing the skills of students in compiling the outline of the essay to compiling the description text. The formulation of the problem in this study can be identified as follows: Can the clustering method improve the writing skills of students in class X IPS 4 SMA N 1 Tengaran odd semester 2014/2015 academic year.

In this study, the researcher will not discuss all the problems of learning English but will only discuss the writing skills of descriptive texts and clustering methods. The purpose of this study was to improve the competency of writing descriptive text skills for class X IPS4 students in the odd semester of SMA N 1 Tengaran in the 2014/2015 academic year.

\section{Writing Skills}

According to Akhadiah et al (1988: 13), writing is a language activity that uses writing as the medium. The writing itself consists of a series of meaningful letters with all the completeness of meaningful letter symbols with all the completeness of writte symbols such as spelling and punctuation. As a form of verbal communication (language), writing can also be defined as an activity to deliver messages using writing 
as the medium. The message is the content or content contained in an article. The writing is a communication system between humans that uses symbols or language symbols that can be seen and agreed upon for their use. In written communication, there are four elements involved. The four elements are (1) the writer as the messenger (2) the message or the content of the writing (3) the channel or writing medium and (4) the reader as the message receiver.

Writing means conveying thoughts, feelings, or considerations through writing. The tool is a language consisting of phrases, clauses, sentences, paragraphs, and discourses. Thoughts conveyed to others must be expressed in supporting words precisely and in accordance with what you want to express. Our words must be arranged regularly in clauses and sentences so that people can grasp what is being said. The more regularly the language used, the easier it is for people to grasp the thoughts transmitted through the language. Therefore, writing skills in school are very important. There are several requirements that a student should have to produce good writing, Syafi'ie (1998: 45) argues that these requirements are (1) the ability to find the problem to be written about, (2) sensitivity to the reader's condition (3) ability to plan writing, (4) ability to use language (5) ability to start writing, and (6) ability to check writing. Writing is essentially an orderly thought process so that what is written is easy to understand by the reader, a writing is said to be good if it has characteristics such as being clear, round, and whole, economical, and fulfilling grammatical rules.

Writing skills are a person's skills to express thoughts, ideas, ideas, and use a series of good and correct written language, a person's writing skills will be good if he has (a) skills to find problems to be written, (b) sensitivity to connections readers, (c) skills in planning research, (d) skills in using language (e) skills to start writing and, (f) skills in examining own essays. These skills will develop if they are supported by reading activities and the richness of their vocabulary. Writing skills are the main competencies that high school graduates want to achieve as stated in PP no.19 of 2005 concerning language graduate competency standards for SMA / MAN students

\section{Clustering}

Clustering is a method of analyzing data, which is often referred to as a data mining method, the purpose of which is to group data with the same characteristics into the same area and with different characteristics to other regions. According to Yohanes Nugroho Widiyanto at the workshop on 54 TEFLIN International Conference 2006, clustering is another brain forming activity that you can use to generate ideas. He is how to use this technique. In the center or your paper write your topic and draw a balloon around it. This is your center or core ballon. Then write whatever ideas. Come to you in ballons around the core. Think about each of these ideas and make more balloons around them. Your richest idea will produce a cluster of balloons. 
29 Improvement of Description Text Writing Skills Through The Application of The Clustering Method for Students

Tin Hadriani

The five step process of clustering :

(1) eliminate inappropiate ideas : if you are writting to inform, eliminate those ideas that are persuasive, if you are writing to persuade decide how material you need; (2) form the remaining ideas, narrow the topic, chose the topic that isn't too board or to narrow in focus review limitation of time and length of the assignents; (3) identy your strongest detail : higlight them in different color ink and maker; (4) identity those detail that are perpose and audience. Eliminate them by drawing over them; (5) form the remaining information write a summary or thesis that state.

\section{Method}

This research was conducted for one semester, namely the odd semester of the 2014/2015 academic year. Research place. This research was conducted in class $X$ IPS 4 odd semester SMA Negeri 2014/2015 academic year, with the research subjects of class X IPS 4 SMA Negeri I Tengaran in the academic year 2014/2015. The number of students was 33 students consisting of 14 male students and 19 female students. In this study, there are 3 data, namely: 1 . Data writing skills descriptive text in the pre-cycle. 2. Skills data writing descriptive text in cycle 1 (one). 3. Data writing skills in the description text in cycle 2 (two). Data on writing descriptive text skills were collected using documentation techniques with learning outcomes documents in the pre-cycle. The data on the skills to write descriptive texts were collected by means of a test technique in the form of a question in cycle 1 (first). The data on the skills to write descriptive texts were collected using a test technique in the form of a question in cycle 2 (second).

There are three kinds of data collection techniques used in this research, namely: documentation, observation, and testing. Documentation data collection techniques are used in the pre-cycle in the form of a teaching journal, namely the researchers' notes on all student activities during the teaching and learning process. The test technique was used to collect data on the skills of writing descriptive text. Data Collection Tools. There are 3 types of data collection tools used in this study, namely: teaching journals, observation sheets, and test items. Validation of writing skills data of Cycle 1 description text through writing assessment rubric.

Data Analysis of Descriptive Text Writing Skills. The data analysis of the descriptive text writing skills was analyzed using a comparative technique, namely comparing the data on the skills of writing descriptive texts in pre-cycle, cycle 1 (one), and cycle 2 (two). Writing Skills Performance Indicators. The method used in this study is a classroom action research method. Actions taken in this study are actions in the pre- cycle researchers have not applied the clustering method in teaching, actions in cycle 1 (first). Researchers have applied the clustering method in large groups, one group consisting of 4 or 5 students. Inaction in cycle 2 (second) the researcher has applied the clustering method in small groups of students working in pairs. Action stages in each cycle. In each cycle, the researcher applies 4 stages of action, namely 1. 
Making action plans (planning). 2. take action (acting). 3. Make observations of the actions taken (observing). 4. Analyze data from action observation (reflecting)

\section{Result and Discussion}

\section{Initial Condition Description (Pre Cycle)}

The skills of writing descriptive texts of students in the pre-cycle are still low. The text that was created was not in accordance with the structure of the descriptive text and the grammar used was also not in accordance with the linguistic features of the descriptive text which mostly used present tenses, noun phrases, and passive voice. The results of writing tests of descriptive text are still low, far below the KKM set by the school, which is 70 . The lowest score achieved by students is 65 while the highest score is 85 on average 70

\section{Description of Cycle 1 (one)}

The value of the skills of writing a descriptive text of students in cycle 1 based on the scoring of the writing rubric which consists of aspects of format and content, organization and coherence, sentence construction, and vocabulary can be seen from the table list of values and the following diagram in the attachment

\section{Reflection}

The skills of writing descriptive texts of students in the pre-cycle are still low. The text that was created was not in accordance with the structure of the descriptive text and the grammar used was also not in accordance with the linguistic features of the descriptive text which mostly used tense present noun phrases, passive voice. The test results in writing descriptive text were still low, far below the KKM set by the school, namely 70 , the lowest score achieved by students was 54 , while the highest score was 85 , the average score was 60 , while the value of writing descriptive text skills of students in cycle one (1) was based on scoring rubric writing consisting of aspects of format and content, organization and coherence, sentence construction and vocabulary as follows: the lowest score is 60 , the highest score is 88 and the average is 62 .

If we compare the skill value of writing descriptive text in the pre-cycle with the skill value of writing descriptive text in cycle one (1) there is an increase, the lowest score is from 54 to 60 . The highest score is from 85 to 88 while the average value is from 62 to 74, then We can conclude that the use of the clustering method can improve the skills in writing descriptive texts.

Table 1. Pre-cycle writing values and cycle one (1)

\begin{tabular}{|l|l|l|l|}
\hline No & value & Pre Cycle & Cycle 1 (one) \\
\hline 1 & The lowest value & 54 & 60 \\
\hline 2 & The highest score & 85 & 88 \\
\hline 3 & Average & 62 & 74 \\
\hline
\end{tabular}


31 Improvement of Description Text Writing Skills Through The Application of The Clustering Method for Students

Tin Hadriani

\section{Reflection cycle 1}

The skills of writing descriptive texts of students in the pre-cycle are still low. The text that was created was not in accordance with the structure of the descriptive text and the grammar used was also not in accordance with the linguistic features of the descriptive text which mostly used tense present, noun phrase, passive voice. The test results in writing descriptive text are still low, far below the KKM set by the school, namely 70 , the lowest score achieved by students is 65 , while the highest score is 85 , the average score is 70 , while the value of writing descriptive text skills of students in cycle one (1) is based on scoring rubric writing consisting of aspects of format and content, organization and coherence, sentence construction and vocabulary as follows: the lowest score is 70 , the highest score is 88 and the average is 74 . If we compare the skill value of writing descriptive text in the pre-cycle with the skill value of writing descriptive text in cycle one (1) there is an increase, the lowest score from 65 to 70 . The highest score is from 85 to 88 while the average value is from 70 to 74 , then We can conclude that the use of the clustering method can improve the skills in writing descriptive texts

\section{Description of Cycle 2 (two)}

\section{Descriptive text writing skills}

The value of students' writing descriptive text skills in cycle 2 , based on writing rubric scoring consisting of aspects of format and content, organization and coherence, sentence construction, and vocabulary, the lowest score is 75 , the highest score is 89 and an average of 78.56 can be seen from the value table and the following diagram in the appendix. The skills of writing descriptive texts of students in the second cycle (2) had increased a lot when compared to the pre-cycle and the first cycle (1). Many of the resulting descriptive texts are in accordance with the structure of the description text and the linguistic features of the description text.

The paragraphs they compile already describe one idea or idea. Based on the writing rubric scoring which consists of aspects of format and content, organization and coherence, sentence construction and vocabulary, the lowest score is 75 , the highest score is 89 with an average score of 78.56. If we compare the skill value of writing descriptive text in the pre-cycle and the first cycle (1) with the first cycle (1) with the second cycle (2) there is a lot of improvement in the skill value between the pre-cycle, the first cycle (1), and the second (2) we can look at the following tables and diagrams.

Table 2. Pre-cycle writing values, first cycle (1) and second cycle (2).

\begin{tabular}{|l|l|l|l|l|}
\hline No & value & Pre Cycle & Cycle 1 (one) & Cycle 2 (two) \\
\hline 1 & The lowest value & 65 & 70 & 75 \\
\hline 2 & The highest score & 85 & 88 & 89 \\
\hline 3 & Average & 70 & 74 & 78.56 \\
\hline
\end{tabular}




\section{Reflection cycle 2}

The skills of writing descriptive texts of students in the second cycle (2) had increased a lot when compared to the pre-cycle and the first cycle (1). Many of the resulting descriptive texts are in accordance with the structure of the description text and the linguistic features of the description text. The paragraphs they compiled already describe one idea or idea. Based on the writing rubric scoring consisting of aspects of format and content, organization and coherence, sentence construction and vocabulary, the lowest score is 75 , the highest score is 89 , the average score is 78.56 .

If we compare the skill value of writing descriptive text in the pre-cycle and the first cycle (1) with the first cycle (1) with the second cycle (2) there is a lot of improvement in the skill value between the pre-cycle, the first cycle (1), and the second (2) we can look at the following tables and diagrams.

\section{Discussion of skills in writing descriptive text}

The skills of writing descriptive texts of students in the pre-cycle are still low. The text that was created was not by the description text structure and the grammar used was also not by the linguistic features of the description text, which used the present tense, noun phare, passive voice. The results of writing tests of descriptive text were still low, far below the KKM set by Seskoalh, which was 75. The lowest score achieved by students was 65 , while the highest score was 85 , the average score was 70 . The value of students' writing descriptive text skills in the first cycle (1) was based on the scoring rubric of writing which consisted of aspects of content format, organization and coherence of sentence construction and vocabulary increased after applying the clustering method. The lowest score is 70 , the highest score is 87 and the average score is 75.18

The skills of writing descriptive texts of students in the second cycle (2) increased when compared to pre-cycle, cycle one (1). Many of the resulting descriptive texts are by the structure of the description text as well as the linguistic features of the descriptive text and the linguistic features of the description text.

The paragraph they compiled already describes one idea or idea.

Based on writing rubric scoring which consists of aspects, format and content, organization and coherence of sentence construction and vocabulary, the lowest score is 75 , the highest is 89 , is 78.56 . If we compare the value of writing descriptive text skills in the pre-cycle, and the first cycle (1) with the second cycle (2) there is a lot of improvement, after the application of the clustering method with a large group consisting of four (4) or five (5) people in the cycle. first (1) and small groups consisting of two (2) people or three (3) people there is an increase as seen in the following table and diagram.

\section{Results of Action}

The skills of writing descriptive texts of students in the pre-cycle are still low. Most of the test scores they achieved were still below the KKM they achieved by the 
33 Improvement of Description Text Writing Skills Through The Application of The Clustering Method for Students

Tin Hadriani

school (75). The lowest score they achieved was 65 , the highest score was 85 , and the average score was 70 . In cycle one (1), there was an increase in writing skills of descriptive text, the lowest score they achieved was 70 , the highest score was 88 and the average was 74 . In cycle two (2), there was a better improvement. The lowest score they achieved was 75 , the highest score was 89 , and the average was 78.56 . From these data, we can conclude that the use of the clustering method can improve students' writing skills of descriptive text

\section{Conclusion}

Based on the data on the assessment of writing descriptive text skills, the application of the clustering method can improve students' writing skills of descriptive text if we look at the pre-cycle values with cycle one (1) and cycle two (2) if pre-cycle the lowest score of students is 65 . The highest score is 85 and an average of 70 , the value achieved by students in cycle one (1) the lowest score was 70 , the highest score was 88 , and the average was 74 , while in cycle two (2) the lowest score was 75 , the highest score was 89 and the average was 78, 56. From the data above, we can conclude that the application of the clustering method can improve the skills of writing descriptive texts for class X IPS 4 SMA N 1 Tengaran odd semester 2014/2015 academic year. Learning the right method should be used so that learning becomes more interesting, fun, and more effective to help students in making descriptive text essays.

\section{References}

Akhadiah, Sabarati, dkk. 1998. Pembinaan Kemampuan Menulis Bahasa Indonesia. Jakarta : Erlangga.

NugrohoYohanes. 2006. The Summit TEFLIN International Conference Work shop Session 19th The Surabaya Mandala Katholic University.

Peraturan Pemerintah no: 19 tahun. 2005. Tentang Standar Kompetensi Lulusan Bahasa untuk Peserta Didik SMA / MAN

Syafi'ie. 1998. Retorika Dalam Menulis Jakarta Depdikbud

(C) 2020 by the authors. Submitted for possible open access publication under the terms and conditions of the Creative Commons Attribution ShareAlike (CC BY SA) license (https://creativecommons.org/licenses/by-sa/4.0/). 